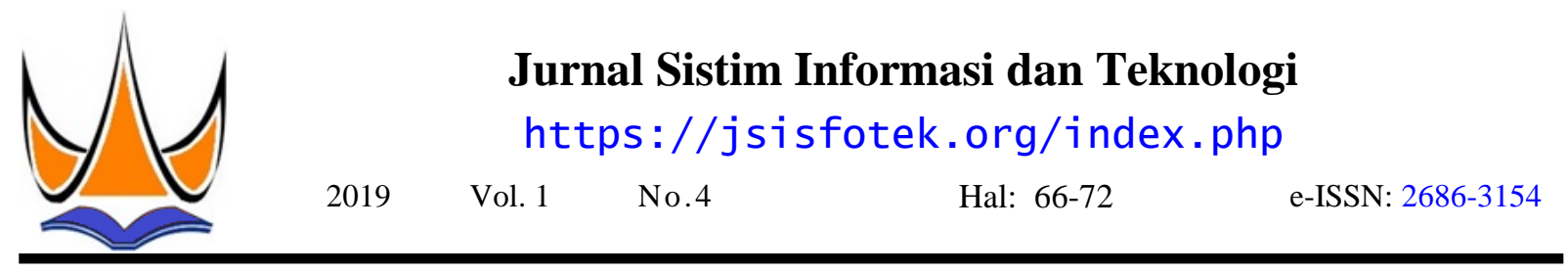

\title{
Kerahasiaan Teks Basis Data MySQL Menggunakan Algoritma Elgamal
}

\author{
Niko Surya Atmaja ${ }^{1 凶}$, Yuhandri Yunus ${ }^{2}$, Sumijan $^{3}$ \\ ${ }^{1,2,3}$ Fakultas Ilmu Komputer, Univeritas Putera Indonesia YPTK Padang \\ niko.suryaatmaja@gmai1.com
}

\begin{abstract}
The common method used to secure a MySQL database is in access control. The technique is the use of a password. To better secure the data sent cryptographic techniques need to be done. This study uses the Elgamal method in conducting cryptography. The results of this study generate MySQL databases in random form during safer delivery and can only be accessed by parties who have a password. So this research can further improve MySQL data security.
\end{abstract}

Keywords: Confidentiality, Cryptography, Elgamal algorithm, Database, MySQL.

\begin{abstract}
Abstrak
Cara yang umum digunakan untuk mengamankan basis data MySQL adalah dalam pengendalian akses. Tekniknya adalah penggunaan kata sandi. Untuk lebih mengamankan data yang dikirim perlu dilakukan teknik kriptografi. Penelitian ini menggunakan metode elgamal dalam melakukan kriptografi. Hasil dari penelitian ini menghasilkan basis data MySQL dalam bentuk acak selama pengiriman lebih aman dan hanya dapat diakses oleh pihak yang mempunyai sandi. Sehingga penelitian ini dapat lebih meningkatkan keamanan data MySQL.
\end{abstract}

Kata kunci: Kerahasiaan, Kriptografi, Algoritma Elgamal, Basis data, MySQL.

(C) 2019 JSisfotek

\section{Pendahuluan}

Pencuri data adalah orang yang tidak berhak mengakses sebuah basis data. Orang ini berada di dalam atau di luar sistem. Para pecuri menargetkan bahwa data yang didapatkan merupakan data penting. Basis data merupakan kumpulan dari beberapa tabel yang terdiri dari beberapa field dan field yang terdiri dari beberapa kolom dan baris yang dapat digunakan untuk menyimpan sebuah data [1]. Tabel adalah matrik yang berisi data dan terlihat berbentuk spreadsheet sederhana, sedangkan kolom adalah satu elemen data terkandung dalam satu jenis data yang sama dan baris adalah sekumpulan data-data yang saling terhubung [2].

MySQL merupakan penerapan dari sebuah sistem manajemen basis data SQL yang bersifat terbuka dan gratis untuk digunakan berbagai pihak [3]. Sehingga MySQL banyak digunakan oleh banyak orang untuk penyimpanan data. Biasanya untuk merahasiakan isi teks basis data MySQL diterapkan penggunaan sandi. Yang menjadi masalah, jika data dari basis data
MySQL dikirimkan kepada pihak yang disetujui maka diperlukan cara agar isi teks basis data MySQL tidak diketahui pencuri data.

Salah satu cara yang digunakan yaitu dengan Salah satu cara yang digunakan yaitu dengan masalah SIS menyimpulkan bahwa kecurian dari merahasiakan isi teks basis data dengan teknik sebuah data maupun informasi dapat diantisipasi kriptografi. Kerahasiaan merupakan tindakan saat dengan aman dan mudah [8].

bertukar informasi dari sekelompok orang ataupun dapat juga satu orang dan menyembunyikannya dari orang yang tidak diberikan izin untuk mengetahuinya [4]. Kerahasiaan juga merupakan penjagaan privasi saat interaksi pada informasi yang diberikan dan juga informasi yang diterima sehingga pihak-pihak yang tidak terkait tidak dapat mengetahui isi informasi yang disampaikan dan di antara ilmu komputer juga terdapat kerahasiaan dalam menjaga sebuah data dan informasi sehingga data yang disimpan, dikelola maupun dikirim memiliki keamanan yang tidak diragukan [5]. Kriptografi merupakan ilmu yang diterapkan untuk merahasiakan sebuah pesan yang bersifat rahasia ataupun pribadi yang dilakukan oleh pihak-pihak yang berkaitan sehingga pihak-pihak yang tidak berkaitan tidak dapat mengetahui informasi yang bersifat rahasia ersebut dan umumnya pesan yang belum dirahasiakan asanya disebut pesan asli (plaintext) dan pesan yang telah dirahasiakan disebut (ciphertext). [6]. Pesan asli (plaintext) merupakan sebuah teks biasa yang biasanya digunakan sebagai input untuk proses pada kriptografi dan pesan rahasia (ciphertext) merupakan pesan yang hanya dapat diketahui pihak yang telah menyepakati kerahasiaan pesan dan memiliki kunci kerahasiaan [7]. Penelitian yang berjudul desain enkripsi dan tanda
tangan elgamal berbasis kisi skema menggunakan Penelitian yang berjudul kriptografi hybird untuk file gambar menggunkan elgamal dan double algoritma 
playfair ciper menyimpulkan bahwa file gambar yang berisi teks dari data yang tersimpan. Teks dari data dirahasiakan dapat memiliki keamanan yang lebih baik yang tersimpan akan dirahasiakan menggunakan [9]. algoritma elgamal.

Penelitian yang berjudul skema otentikasi pengguna jarak jauh berbasis dua faktor menggunakan kriptografi elgamal menyimpulkan bahwa algoritma elgamal dapat digunakan untuk keamanan jenis apapun yang berbasiskan tulisan [10]. Penelitian yang berjudul analisis kombinasi algoritma elgamal dan algoritma LUC dalam keamanan file menyimpulkan bahwa keamanan file menjadi lebih baik [11].

Berdasarkan beberapa penelitian terdahulu yang mendapatkan kunci public dan kunci private. Setelah menggunakan algoritma elgamal untuk menyelesaikan mendapatkan dua kunci yaitu kunci public dan kunci berbagai masalah kerahasiaan data, maka peneliti private, maka kunci public digunakan untuk menggunakan algoritma elgamal untuk merahasiakan mengenkripsi pesan dan kunci private digunakan untuk isi teks basis data MySQL. Algoritma elgamal mendekripsi pesan. Rumus pembentukan kunci public merupakan sebuah algoritma yang dapat melakukan dan kunci private yaitu :

enkripsi dan dekripsi berdasarkan kunci asimetris yang

artinya kunci public dan kunci private berbeda sehingga untuk melakukan proses enkripsi dan dekripsi juga dilakukan dengan jalan dan rumus yang berbeda [12]. Enkripsi merupakan teknik yang digunakan untuk merahasiakan teks ataupun data-data yang bersifat teks dan dekripsi merupakan teknik yang digunakan untuk membaca informasi [13]. Dengan adanya teknik kriptografi menggunakan algoritma elgamal maka isi teks basis data MySQL dapat dirahasiakan dari pencuri data.

\section{Metodologi Penelitian}

Metodologi penelitian pada penelitian ini meliputi beberapa tahapan yaitu menggunakan basis data MySQL, pembentukan kunci algoritma elgamal, enkripsi algoritma elgamal, dekripsi algoritma elgamal dan hasil. Gambar 1 adalah tahapan proses penelitian yang disusun berdasarkan tahapan awal hingga akhir penelitian.

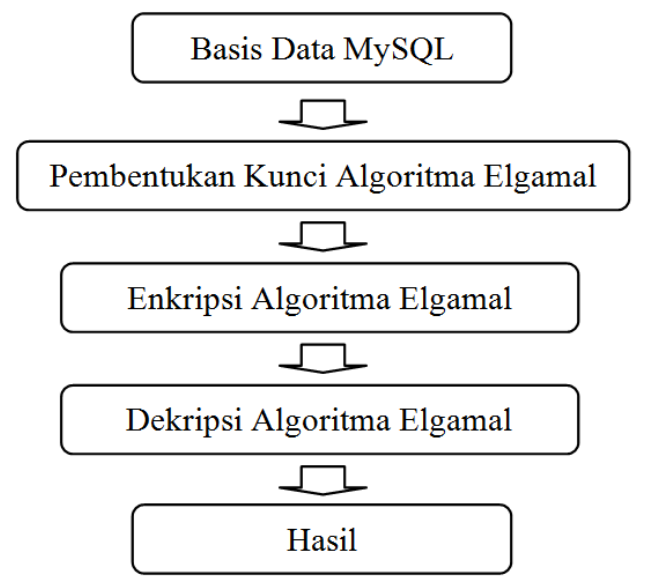

Gambar 1. Tahapan Proses Penelitian

\subsection{Basis Data MySQL}

$\mathrm{y}=\mathrm{g}^{\mathrm{x}} \bmod \mathrm{p}$.

Keterangan :

$\mathrm{y}$ : identitas kunci public

$\mathrm{g}$ : bilangan prima pertama

$\mathrm{x}$ : bilangan prima kedua

mod : sisa bagi

$\mathrm{p}$ : bilangan prima ketiga

Algoritma pembentukan kunci public dan kunci private disajikan pada Gambar 2.

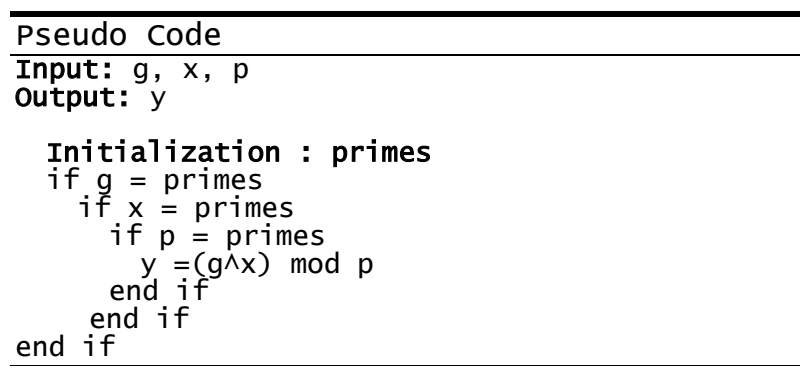

Gambar 2. Algoritma pembentukan kunci

Tahapan pembentukan kunci publik dan kunci privat yang dijelaskan sebagai berikut :

1. Gunakan Bilangan Prima (g)

Bilangan prima $(\mathrm{g})$ merupakan nilai pembentukan kunci pertama untuk mendapatkan kunci y.

2. Gunakan Bilangan Prima (x)

Bilangan prima $(\mathrm{x})$ merupakan nilai pembentukan kunci kedua untuk mendapatkan kunci y.

\section{Gunakan Bilangan Prima (p)}

Bilangan prima (p) merupakan nilai pembentukan kunci ketiga untuk mendapatkan kunci y.

Basis data yang akan dirahasiakan adalah MySQL. Di 4. Hitung Nilai y dalam basis data MySQL terdapat tabel-tabel yang

Jurnal Sistem Informasi dan Teknologi Vol . 1 No. 4 (2019) 66-72 
Setelah menentukan tiga bilangan prima yaitu $\mathrm{g}, \mathrm{x}$ dan $\mathrm{p}$ maka tahapan selanjutnya menghitung nilai $\mathrm{y}$.

5. Nilai y, g dan p Merupakan Kunci Publik.

Setelah melakukan perhitungan nilai y maka didapatkan kunci publik yang digunakan untuk mengenkripsi teks. Kunci publik adalah y, g dan p.

6. Nilai $x$ dan $\mathrm{p}$ Merupakan Kunci Privat.

Setelah melakukan perhitungan nilai y maka didapatkan kunci privat yang digunakan untuk mendekripsi teks. Kunci privat adalah $\mathrm{x}$ dan $\mathrm{p}$.

\subsection{Enkripsi Algoritma Elgamal}

Pada algoritma elgamal untuk melakukan enkripsi isi teks basis data MySQL, terlebih dahulu harus memiliki kunci untuk enkripsi yaitu kunci public. Setelah mendapatkan kunci public (y, g, p) yang digunakan untuk mengenkripsi teks. Rumus untuk mengenkripsi pesan yaitu :

Gamma :

$\gamma=\mathrm{g}^{\mathrm{k}} \bmod \mathrm{p}$

Dimana :

$\gamma$ : nilai gamma pembentuk cipher pertama

$\mathrm{g}$ : bilangan prima pertama

$\mathrm{k}$ : bilangan prima acak

$\bmod$ : sisa bagi

$\mathrm{p}$ : bilangan prima ketiga

Delta :

$\delta=\mathrm{y}^{\mathrm{k}} \cdot \mathrm{m} \bmod \mathrm{p}$

Dimana :

$\delta$ : nilai delta pembentuk cipher kedua

$\mathrm{y}$ : identitas kunci public

$\mathrm{k}$ : bilangan prima acak

$\mathrm{m}$ : nilai ASCII dari teks yang akan dirahasiakan

mod : sisa bagi

$\mathrm{p}$ : bilangan prima ketiga

Algoritma enkripsi teks disajikan pada Gambar 3.

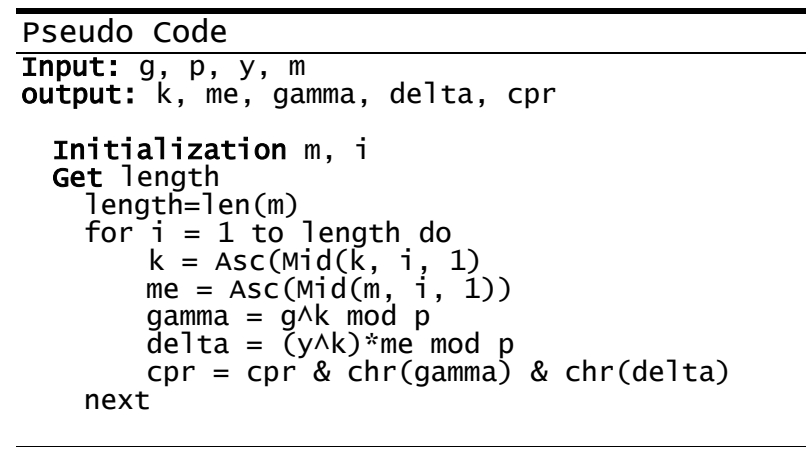

Gambar 3. Algoritma enkripsi

Tahapan proses enkripsi dijelaskan sebagai berikut :

\section{Plaintext}

Plaintext yang akan dienkripsi adalah isi dari tabel basis data MySQL.

2. Ubah Plaintext Menjadi Kode ASCII Dan Susun Menjadi Blok-Blok Nilai m.

3. Menghasilkan Susunan Nilai m.

4. Tentukan Bilangan Acak k Sepanjang Jumlah Plaintext.

5. Menghasilkan Bilangan Acak k.

Bilangan acak $\mathrm{k}$ yang telah dihasilkan akan digunakan sebagai pemangkat pesan.

6. Enkripsikan Setiap Blok m.

Enkripsi setiap blok m dengan enkripsi Gamma dan Delta.

\section{Menghasilkan Ciphertext.}

Satukan nilai gamma dan nilai delta sehingga menjadi ciphertext.

\subsection{Dekripsi Algoritma Elgamal}

Pada algoritma elgamal untuk melakukan dekripsi isi ciphertext basis data MySQL, terlebih dahulu harus memiliki kunci untuk dekripsi yaitu kunci private Setelah mendapatkan kunci private (x, p) yang digunakan untuk mendekripsi teks maka dapat dilakukan proses dekripsi. Rumus untuk mendekripsi pesan yaitu :

$\mathrm{m}=\gamma \cdot \delta(\mathrm{p}-1-\mathrm{x}) \bmod \mathrm{p}$

Dimana :

$\gamma$ : nilai gamma pembentuk cipher pertama

$\delta$ : nilai gamma pembentuk cipher kedua

$\mathrm{m}$ : nilai ASCII dari teks yang akan dirahasiakan

$\mathrm{x}$ : bilangan prima kedua

mod : sisa bagi

$\mathrm{p}$ : bilangan prima ketiga

Algoritma dekripsi teks rahasia disajikan pada Gambar 4.

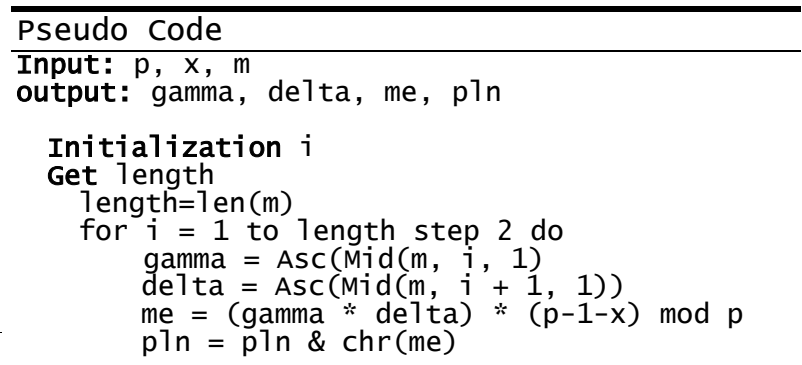


next

Gambar 4. Algoritma deskripsi

Tahapan proses enkripsi dijelaskan sebagai berikut :

\section{Ciphertext}

Ambil ciphertext yang akan didekripsi menggunakan algoritma elgamal.

2. Pisahkan Nilai Gamma dan Delta Pada Pesan Rahasia (Ciphertext).

Lakukan pemisahan urutan teks ganjil dan teks genap. Teks ganjil merupakan nilai gamma dan teks genap merupakan nilai delta.

3. Menghasilkan Nilai Gamma dan Delta

Nilai gamma dan delta didapatkan melakukan pemisahan dan disatukan kelompok ganjil dan genap.

4. Konversi Nilai Gamma dan Delta Menjadi Plaintext

Konversi nilai gamma dan delta menjadi plaintext Sehingga menghasilkan plaintext yang dihasilkan berupa $m$ dalam desimal ASCII.

\section{Menghasilkan Plaintext}

Lakukan penyusunan pesan $\mathrm{m}$ yang dihasilkan dan lakukan konversi karakter sehingga menjadi plaintext.

\subsection{Hasil}

Hasil yang didapatkan setelah melakukan proses pembentukan kunci dan proses enkripsi yaitu kerahasiaan isi teks basis data MySQL berupa ciphertext dan hasil yang didapatkan setelah melakukan proses dekripsi yaitu isi teks basis data MySQL yang telah dirahasiakan menjadi isi teks basis data MySQL yang asli berupa plaintext.

\section{Hasil dan Pembahasan}

Data yang digunakan untuk pengujian kerahasiaan teks basis data MySQL yaitu data login. Data ini digunakan sebagai uji coba untuk merahasiakan isi dari setiap tabel pada basis data MySQL. Algoritma yang digunakan untuk merahasiakan teks yang terdapat Setelah mendapatkan kunci public dan kunci private dalam tabel basis data yaitu Algoritma Elgamal. Data tahap selanjutnya yaitu melakukan proses enkripsi

login berisi teks nama pengguna, sandi dan status. Teks menggunakan kunci public yaitu $\mathrm{y}, \mathrm{g}$ dan $\mathrm{p}$.

yang terdapat pada field password akan dirahasiakan dengan algoritma elgamal dengan mengenkripsi teks di dalam tabel basis data MySQL. Untuk dapat merahasiakan sebuah teks maka di dalam algoritma elgamal diperlukan pembentukan dua buah kunci yaitu kunci public dan kunci private. Dimana masing-masing kunci memiliki fungsi yang berbeda, kunci public digunakan untuk mengenkripsi atau merahasiakaan teks basis data MySQL dan kunci private digunakan untuk mendekripsi teks atau mengembalikan kerahasiaan teks menjadi teks yang dapat dibaca. Data login yang isi

dari field sandi akan dirahasiakan menggunakan algoritma elgamal dapat dilihat pada Tabel 1.

Tabel 1. Isi Teks Basis Data MySQL

\begin{tabular}{lll}
\hline Nama_pengguna & Sandi & Status \\
\hline Admin & admin & Admin \\
Niko & nsa_st & Pengguna \\
Dino & dno_lk & Pengguna \\
Heni & hni_nv & Pengguna \\
Rahmayuni & rhm_ns & Pengguna \\
Ilham & ilh_tb & Pengguna \\
Bambang & bmb_rp & Pengguna \\
Secar & scr_123 & Pengguna \\
Ana & ana_111 & Pengguna \\
Anton & ant_pw & Pengguna \\
Faisal & fsl_000 & Pengguna \\
Maulida & mld_ww & Pengguna \\
Saripah & srp_h1 & Pengguna \\
M.Ali & m_ali & Pengguna \\
Tusim & tsm_ah & Pengguna \\
\hline
\end{tabular}

Berdasarkan Tabel 1 bahwa Teks Basis Data MySQL yang telah dijabarkan maka untuk merahasiakan teks dari field sandi dilakukan langkah dari algoritma elgamal.

Proses pembentukan kunci :

1. Bilangan prima yang digunakan adalah 127.

2. Bilangan acak pertama yang digunakan adalah 13 .

3. Bilangan acak kedua yang digunakan adalah 17 .

4. Hitung nilai $y$ :

$$
\begin{aligned}
\mathrm{y} & =\mathrm{g}^{\mathrm{x}} \bmod \mathrm{p} \\
& =13^{17} \bmod 127 \\
& =44
\end{aligned}
$$

Sehingga diperoleh kunci public :

$y=44$

$\mathrm{g}=13$

$\mathrm{p}=127$

Dan diperoleh kunci private :

$\mathrm{p}=127$

$x=17$ 
Proses Enkripsi:

Diketahui:

Plaintext : "admin"

Kunci public :

$\mathrm{p}=127$

$\mathrm{g}=13$

$\mathrm{y}=44$

Nilai k yang digunakan yaitu :

$\mathrm{k} 1=11$

$\mathrm{k} 2=13$

$\mathrm{k} 3=17$

$\mathrm{k} 4=19$

$\mathrm{k} 5=23$

Penyelesaian :

Ubah pesan asli (plaintext) ke dalam ASCII :

$\mathrm{a}=97$

$\mathrm{d}=100$

$\mathrm{m}=109$

$\mathrm{i}=105$

$\mathrm{n}=110$

Sehingga nilai $\mathrm{m}$ adalah sebagai berikut :

$\mathrm{m} 1=97$

$\mathrm{m} 2=100$

$\mathrm{m} 3=109$

$\mathrm{m} 4=105$

$\mathrm{m} 5=110$

Hitung gamma $(\gamma)$ dengan rumus $\gamma=\mathrm{g}^{\mathrm{k}} \bmod \mathrm{p}$ $\gamma 1=13^{11} \bmod 127$ $=82$

$\gamma 2=13^{13} \bmod 127$

$$
=15
$$

$\gamma 3=13^{17} \bmod 127$

$$
=44
$$

$\gamma 4=13^{19} \bmod 127$

$$
=70
$$

$\gamma 5=13^{23} \bmod 127$

$$
=36
$$

Hitung delta dengan rumus $\delta=\mathrm{y}^{\mathrm{k}} \cdot \mathrm{m} \bmod \mathrm{p}$ $\delta 1=44^{11} .97 \bmod 127$

$$
=90
$$

$\delta 2=44^{13} .100 \bmod 127$

$$
=98
$$

$\delta 3=44^{17} .109 \bmod 127$

$$
=5
$$

$\delta 4=44^{19} .105 \bmod 127$

$$
=28
$$

$\delta 5=44^{23} .110 \bmod 127$

$$
=126
$$

Susun hasil perhitungan gamma $(\gamma)$ dan delta $(\delta)$

ASCII Ciphertext : 82, 90, 15, 98, 44, 5, 70, 28, 36, 126

Ubah ASCII Ciphertext menjadi karakter :

$82=\mathrm{R}$

$90=\mathrm{Z}$

$15=$

$98=$

$44=\mathrm{b}$
$5=$,

$70=$

$28=\mathrm{F}$

$36=\$$

$126=\sim$

Ciphertext : RZ b, F \$

Setelah diimplementasikan pada seluruh data maka hasil enkripsi dapat dilihat pada Tabel 2.

Tabel 2. Data Uji Setelah Proses Enkripsi

\begin{tabular}{lll}
\hline Nama_pengguna & Sandi & Status \\
\hline Admin & RZ b, F \$ & Admin \\
Niko & R3 d,]FN\$J) & Pengguna \\
Dino & RQ 9,KFN\$)G & Pengguna \\
Heni & RE 9,wFN\$ )3 & Pengguna \\
Rahmayuni & R' k, FN\$ )D & Pengguna \\
Ilham & RB t,TFN\$Y)z & Pengguna \\
Bambang & RW , FN\$;)U & Pengguna \\
Secar & R\$ @,5FN\$d)G: & Pengguna \\
Ana & RZ 9, JFN\$)=Gq & Pengguna \\
Anton & RZ 9, $\{$ FN\$ ) & Pengguna \\
Faisal & RK d,aFN\$U)mGM & Pengguna \\
Maulida & R6 t,GFN\$ ) & Pengguna \\
Saripah & R\$ B,nFN\$ $\$)=$ & Pengguna \\
M.Ali & R6 7,]FV\$3 & Pengguna \\
Tusim & R! d, FN\$:)X & Pengguna \\
\hline
\end{tabular}

Berdasarkan Tabel 2 teks basis data MySQL yang telah dijabarkan maka untuk merahasiakan teks dari field password dilakukan langkah dari algoritma elgamal berikut :

Proses Dekripsi :

Langkah-langkah penyelesaian proses dekripsi adalah sebagai berikut :

Diketahui :

Ciphertext: "RZ b, F \$ "

Kunci private :

$\mathrm{p}=127$

$\mathrm{x}=17$

Penyelesaian :

Pisahkan nilai gamma dan delta pada pesan rahasia

(Ciphertext).

$\gamma=$ Ciphertext urutan ganjil.

$\delta=$ Ciphertext urutan genap.

Sehingga menjadi :

$\gamma=\mathrm{R} \quad, \mathrm{F} \$$

$\delta=\mathrm{Zb} \quad \sim$

Ubah Ciphertext menjadi kode ASCII :

Nilai gamma :

$\gamma 1=\mathrm{R}=82$

$\gamma 2=\quad=15$

$\gamma 3=, \quad=44$

$\gamma 4=\mathrm{F}=70$

$\gamma 5=\$=36$

Nilai delta :

$\delta 1=\mathrm{Z}=90$

$\delta 2=\mathrm{b}=98$ 


$$
\begin{array}{ll}
\delta 3= & =5 \\
\delta 4= & =28 \\
\delta 5=\sim & =126
\end{array}
$$

Hitung $\mathrm{m}$ (pesan asli) dengan rumus : $\mathrm{m}=\delta . \gamma(\mathrm{p}-1-\mathrm{x}) \bmod \mathrm{p}$.

Sehingga :

$$
\begin{aligned}
\mathrm{m} 1 & =82.90(127-1-17) \bmod 127 \\
& =7390 * 109 \bmod 127 \\
& =805510 \bmod 127 \\
& =97 \\
\mathrm{~m} 2 & =15.98(127-1-17) \bmod 127 \\
& =1470 * 109 \bmod 127 \\
& =160230 \bmod 127 \\
& =100 \\
\mathrm{~m} 3 & =44.5(127-1-17) \bmod 12 \\
& =220 * 109 \bmod 127 \\
& =23980 \bmod 127 \\
& =109 \\
\mathrm{~m} 4 & =70.28(127-1-17) \bmod 127 \\
& =1960 * 109 \bmod 127 \\
& =213640 \bmod 127 \\
& =105 \\
\mathrm{~m} 5 & =36.126(127-1-17) \bmod 127 \\
& =4536 * 109 \bmod 127 \\
& =494424 \bmod 127 \\
& =110
\end{aligned}
$$

ASCII Plaintext : 97, 100, 109, 105, 110

Ubah ASCII Plaintext menjadi karakter :

$97=\mathrm{a}$

$100=\mathrm{d}$

$109=m$

$105=\mathrm{i}$

$110=\mathrm{n}$

Plaintext : "admin"

Uji coba dilakukan pada isi field password yang telah dirahasiakan pada tabel data login, maka hasil dari dekripsi algoritma elgamal dengan kunci private (p, $\mathrm{x}$ ) $=(127,17)$ dapat dilihat pada Tabel 3 .
Tabel 3. Data Uji Setelah Proses Dekripsi

\begin{tabular}{lll}
\hline Nama_pengguna & Sandi & Status \\
\hline Admin & admin & Admin \\
Niko & nsa_st & Pengguna \\
Dino & dno_lk & Pengguna \\
Heni & hni_nv & Pengguna \\
Rahmayuni & rhm_ns & Pengguna \\
Ilham & ilh_tb & Pengguna \\
Bambang & bmb_rp & Pengguna \\
Secar & scr_123 & Pengguna \\
Ana & ana_111 & Pengguna \\
Anton & ant_pw & Pengguna \\
Faisal & fsl_000 & Pengguna \\
Maulida & mld_ww & Pengguna \\
Saripah & srp_h1 & Pengguna \\
M.Ali & m_ali & Pengguna \\
Tusim & Tsm_ah & Pengguna \\
\hline
\end{tabular}

\section{Kesimpulan}

Setelah melakukan tahapan proses penelitian mengenai kerahasiaan teks basis data MySQL menggunakan algoritma elgamal dapat disimpulkan bahwa algoritma elgamal dapat digunakan untuk merubah teks yang terdapat di dalam basis data MySQL menjadi teks rahasia (ciphertext) sehingga tidak dapat di baca oleh pencuri data.

\section{Daftar Rujukan}

[1] Warman, Sultan (2018). Perancangan Sistem Simulasi Data Terintegrasi (Studi Kasus : Data SIM, KTP dan KTM). TEKNOIF, 6(3), 100-109. https://doi.org/10.21063/JTIF.2018.V6.2

[2] Enterprise (2018). HTML, PHP dan MySQL Untuk Pemula. 1st ed. Bandung: PT. Elex Media Komputindo.

[3] Asaad, \& Segerey (2017). School Management Application Using iOS. Academic Journal of Nawroz University, 7(4), 3844. https://doi.org/10.25007/ajnu.v7n4a269

[4] Al-Zubi, M., \& Abu-Shareha, A. A. (2019). Efficient signcryption scheme based on El-Gamal and Schnorr. Multimedia Tools and Applications, 78(9), 11091-11104. https://doi.org/10.1007/s11042-018-6636-7

[5] Dwork (2018). The Future Of The Journal Of Privacy And Confidentiality. Journal of Privacy and Confidentiality, 8(1), 12. https://doi.org/10.29012/jpc.708

[6] Ordonez, A. J., Gerardo, B. D., \& Medina, R. P. (2018). Digital signature with multiple signatories based on modified ElGamal Cryptosystem. 5th International Conference on Business and Industrial Research (ICBIR), Bangkok, 89-94. https://doi.org/10.1109/ICBIR.2018.8391172

[7] Kalsi, S., Kaur, H., \& Chang (2018). DNA Cryptography and Deep Learning using Genetic Algorithm with NW algorithm for Key Generation. Journal of Medical Systems, 42(17). https://doi.org/10.1007/s10916-017-0851-z

[8] Gupta, D. S., \& Biswas, G. P. (2017). Design of lattice-based ElGamal encryption and signature schemes using SIS problem. Wiley Online Library, https://doi.org/10.1002/ett.3255

[9] Hardi, S. M., Tarigan, J. T., \& Safrina, N. (2017). Hybrid Cryptosystem For Image File Using Elgamal And Double Playfair Cipher Algorithm. Journal of Physics: Conference Series, 978(1), 012068. https://doi.org/10.1088/17426596/978/1/012068

[10] Soni, P., Ali, R., \& Pal, A.K. (2017). A Two-factor based Remote User Authentication Scheme using ElGamal 
Cryptosystem. Proceedings of the ACM Workshop on Internet [12] Jannati, H., \& Bahrak, B. (2017). An Oblivious Transfer of Things (IoT) Security: Issues and Innovations, Article No. 3. Protocol Based on Elgamal Encryption for Preserving Location https://doi.org/10.1145/3084030.3084031

Privacy. Wireless Personal Communications, 97(2), 3113-3123

[11] Mawengkang, H., Siregar, A. F., \& Efendi, S. (2018).

Combination Analysis Of Elgamal Algorithm and LUC

Algorithm In File Security. IOP Conference Series: Materials Science and Engineering, Volume 420, conference 1, https://doi.org/10.1088/1757-899x/420/1/012130

13] D. Rachmawati, A. S., Harahap, \& Purba, R. N. (2018). A Hybird Cryptosystem Approach For Data Security By Using Triple DES Algorithm And Elgamal Algorithm. IOP Conference Series: Materials Science and Engineering, 453, 012018. https://doi.org/10.1088/1757-899x/453/1/012018 